\title{
O USO DE IMAGENS DE SATÉLITE COMO RECURSO DIDÁTICO PARA O ESTUDO DA CATEGORIA LUGAR
}

\author{
Felipe Correa dos Santos \\ Mestrando do Programa de Pós-Graduação em Geografia da \\ Universidade Federal de Santa Maria \\ felipecorrea_rs@hotmail.com \\ Waterloo Pereira Filho \\ Prof. Dr. do Departamento de Geociências da \\ Universidade Federal de Santa Maria \\ waterloopf@gmail.com
}

Resumo: O uso de sensoriamento remoto como recurso didático pode trazer grandes contribuições à sociedade. Apesar das diversas utilidades que as imagens de satélite podem trazer para as práticas docentes, seu uso ainda é muito pequeno. O professor deve organizar as atividades em sala de aula dando sentido no que está sendo estudado, apresentar ao aluno uma Geografia mais próxima da realidade, de seu cotidiano. Neste contexto, o presente trabalho visa desenvolver e avaliar uma seqüência didática para o estudo da categoria lugar, com o auxílio de imagens de satélites, confecção de desenhos e mapas mentais, aplicada aos alunos da $5^{\text {a }}$ série do Ensino Fundamental da Escola Paulo Devanier Lauda no Bairro Tancredo Neves, Santa Maria - RS. Em forma de desenhos, os alunos representaram seus locais de vivência de acordo com suas experiências do cotidiano. Com a imagem do satélite Ikonos do Núcleo Habitacional Tancredo Neves, os alunos interpretaram elementos geográficos e transcreveram para o papel vegetal. Através da análise de mapas mentais confeccionados antes e depois do uso da imagem de satélite, constataram-se diversas melhorias no conhecimento espacial do espaço vivido pelos alunos. A seqüência didática proporcionou motivação aos alunos para realização do estudo do lugar. Com as imagens puderam-se verificar os locais conhecidos pelos alunos e ampliar sua visão sobre o seu espaço vivido.

Palavras-chave: sensoriamento remoto, imagens de satélite, ensino de Geografia, estudo do lugar.

\section{THE USE OF SATELLITE IMAGES AS A TEACHING RESOURCE TO THE STUDY OF PLACE} CATEGORY

Abstract: The use of remote sensing as a didactic resource can bring great contributions to society. Despite the various utilities that satellite images can bring to the teaching practice, its usage is quite small. The teacher should organize the activities in classroom giving meaning to what is being studied, present to the student a Geography closer to his reality, to his quotidian. In this context, this work aims to develop and evaluate a didactic sequence to the study of the place category, with the satellite images help, confection of drawings and mental maps, applied to the 5th grade elementary school students of Paulo Devanier Lauda School in Tancredo Neves district, Santa Maria - RS. In form of drawings, the students represented their living places according to their quotidian experiences. With the Ikonos satellite images of Tancredo Neves habitation center, the students interpreted geographic elements and transcript to parchment paper. The mental map analysis made before and after the use of satellite image, it was found various improvements on the spatial knowledge in the space lived by the students. The didactic sequence enabled motivation to the students for the realization of the place study. With the images it was possibly to verify the locations known by the students and broaden their view on their living space.

Keywords: remote sensing, satellite images, teaching geography, place study. 


\section{INTRODUÇÃO}

O avanço das tecnologias trouxe profundas reformulações quanto à formação de educadores. Ao invés de simples transmissores, os professores passaram a ser estimuladores dos alunos para que construam seu conhecimento, buscando nos recursos tecnológicos uma nova forma de aprendizagem, mais dinâmica, construtiva, mudando dessa forma o conceito de educar.

Proporcionar uma educação voltada para a utilização dos modernos recursos oferecidos pelo avanço atual da tecnologia tem sido apontado como uma das maiores dificuldades dos professores na realidade brasileira. Tendo em vista, que a garantia para um aprendizado bem sucedido no ensino fundamental depende da capacidade do professor de despertar a atenção de seus alunos, preparando aulas criativas que atendam as expectativas dos estudantes.

Cabe ao professor de Geografia proporcionar situações em sala de aula que despertem o interesse e a curiosidade dos alunos sobre o conteúdo geográfico estudado. O aluno necessita participar ativamente das aulas de Geografia, para isso o professor deve atuar com métodos lúdicos, através de atividades práticas ligadas ao conteúdo. "Motivar os alunos não é tarefa fácil. Muitas vezes o professor conhece as teorias e técnicas de motivação da aprendizagem, mas ele próprio, não está motivado para ensinar. Os alunos percebem essa desmotivação e, apesar das técnicas e dos métodos de ensino utilizados, não demonstram maior entusiasmo pela matéria” (PILETTI, 1991, p.236). Assim, tornase necessário que o professor procure constantemente novos meios e materiais didáticos para trabalhar os diferentes temas da Geografia em sala de aula.

Com o advento de novas tecnologias, a inclusão digital passou a fazer parte do ensino em geral e deixaram de serem utilizadas somente por profissionais técnicos. Isso pode ser percebido com a adaptação dos Parâmetros Curriculares Nacionais em relação às novidades tecnológicas e sua socialização em prol da formação de um cidadão crítico e participativo na sociedade.

Neste contexto, Santos (2002) enfatiza que a escola recebe uma nova atribuição, a de constituir-se responsável pela comunicação sócio-cultural que acaba por tornar-se um espaço privilegiado para promover a socialização do conhecimento, que por meio dos Parâmetros 
Curriculares Nacionais (PCN’s), enfatiza na disciplina de Geografia o uso do Sensoriamento Remoto, considerado como instrumento de tomada de decisão na área técnica.

Apesar das diversas utilidades que as imagens de satélite podem trazer para as práticas docentes, é muito pequena a sua utilização. Muitos professores encontram dificuldades em saber onde adquirir e como utilizar as imagens de satélite em suas práticas pedagógicas. Ainda há os professores que vêem um grande desafio em associar os produtos gerados pelo avanço tecnológico às práticas pedagógicas, devido à insistência em utilizar os métodos tradicionais de ensino voltados à somente aulas expositivas e transmissão de conteúdo.

O uso do Sensoriamento Remoto incorporado ao contexto escolar, proporciona o aluno a interação com o meio em que vive, proporcionando-lhe compreender as relações espaciais, humanas e ambientais (PEREIRA, 2007). Acredita-se que a ampliação do enfoque à paisagem local e o espaço vivido através do emprego de imagens de satélite possibilita tanto a inserção de um novo instrumental para o ensino, quanto à socialização do sensoriamento remoto.

De acordo com Kramer et. al. (2009), com o uso das tecnologias espaciais introduzidas no ensino como forma de instigar o aluno ao aprendizado, tendo um melhor entendimento e visualização das relações e conflitos existentes no cenário geográfico, os alunos, em geral, demonstraram entender o ambiente em que vivem refletindo e questionando a sua realidade, identificando-se no material e buscando formas de intervir para solucionar os problemas sócio-ambientais encontrados.

Nesse aspecto, Corazza (2008) aponta que as imagens de satélite podem se configurar como potenciais recursos didático-pedagógicos se devidamente empregadas. O aspecto colorido, a possibilidade de ver espaços como o vivido sob uma ótica diferente e de acompanhar as mudanças ocorridas na superfície terrestre de maneira instantânea, por si só são capazes de promover no aluno a motivação inicial necessária a todo processo de aprendizagem.

Para que os alunos possam visualizar e extrair as informações das imagens de satélite, precisam ser orientados sobre os elementos de interpretação de imagens, que são: tonalidade, cor, textura, tamanho, forma, sombra, altura, padrão e localização. Segundo Florenzano (2002), estes elementos podem ser identificados, independentemente da 
resolução escala, podendo obter informações de objetos, áreas ou fenômenos. A descrição dos elementos de interpretação de imagens é apresentada no Quadro 1.

\begin{tabular}{|c|c|}
\hline \begin{tabular}{|l|} 
Elementos de \\
interpretação
\end{tabular} & Principais características \\
\hline Tonalidade & $\begin{array}{l}\text { Utilizada para interpretar imagens em preto e branco, representadas por } \\
\text { diferentes tonalidades, ou tons de cinza. }\end{array}$ \\
\hline Cor & $\begin{array}{l}\text { Elemento usado na interpretação de fotografias ou imagens coloridas. } \\
\text { Destaca-se a maior facilidade em interpretar imagens coloridas, porque o } \\
\text { olho humano distingue cem vezes mais cores do que tons de cinza. }\end{array}$ \\
\hline Textura & $\begin{array}{l}\text { Refere-se ao aspecto liso ou rugoso dos objetos em uma imagem. Contém } \\
\text { informações quanto às variações de tons ou níveis de cinza/cor de uma imagem. }\end{array}$ \\
\hline Tamanho & $\begin{array}{l}\text { É uma função da escala da fotografia ou imagem, relativo aos objetos na } \\
\text { imagem. É um elemento importante na identificação de objetos. }\end{array}$ \\
\hline Forma & $\begin{array}{l}\text { Elemento tão importante, que alguns objetos, feições ou superfícies são } \\
\text { identificados apenas com base nesse elemento. De modo geral, formas } \\
\text { irregulares são indicadoras de objetos naturais, enquanto formas regulares } \\
\text { indicam objetos artificiais ou culturais, construídos pelo homem. }\end{array}$ \\
\hline Sombra & $\begin{array}{l}\text { Permite obter informações estimadas sobre a altura dos objetos em imagens } \\
\text { bidimensionais. Por outro lado, a sombra de objetos representada em uma } \\
\text { imagem pode ocultar a visualização dos objetos por ela encobertos. }\end{array}$ \\
\hline Altura & $\begin{array}{l}\text { Permite obter informações sobre a altura dos objetos em fotografias ou } \\
\text { imagens em 3D. }\end{array}$ \\
\hline Padrão & $\begin{array}{l}\text { Ajuda na identificação de objetos, uma vez que ele se refere ao arranjo } \\
\text { espacial ou à organização desses objetos em uma superfície. }\end{array}$ \\
\hline Localização & $\begin{array}{l}\text { A localização de um objeto ajuda na sua identificação. As áreas urbanas, por } \\
\text { exemplo, podem ser identificadas por sua proximidade de rodovias, rios e litorais. }\end{array}$ \\
\hline
\end{tabular}

Quadro 1 - Descrição sobre os elementos de interpretação de imagens.

Fonte: Florenzano, 2002.

O Sensoriamento Remoto representa para a Geografia uma nova ferramenta para a análise espacial. Para os alunos apresenta-se como uma nova maneira de conhecer a realidade do mundo que o cerca. Ao professor de Geografia, enquanto profissional da ciência e da educação, cabe se apropriar dessa nova tecnologia para auxiliar seus alunos uma formação em uma perspectiva crítica (SILVA e CHAVES, 2009).

Neste aspecto, Móta (2007, p.122) destaca que:

Diante da apropriação e expansão de novas tecnologias pela sociedade, torna-se necessário que o educador acompanhe essas mudanças e as transmita para o aluno de forma adequada e atualizada. O uso do sensoriamento remoto no ensino, faz com que o aluno tenha um olhar geográfico do lugar em que vive e entenda a sua relação com os diferentes lugares e com o mundo. 
Entender o lugar em que se vive possibilita ao aluno conhecer a sua história e conseguir entender toda a dinâmica de acontecimentos que o rodeia. Para isso o professor precisa incentivar os alunos ao entendimento do seu lugar de vivência, através do estudo das relações das pessoas com o meio físico, a natureza e suas experiências e relações com o espaço e lugar.

Tuan (1980) se refere ao termo topofilía para estudar a percepção e os valores que as pessoas agregam ao meio em que vivem. Para ele, a topofilía seria uma afetividade que ligaria as pessoas ao lugar. Do mesmo modo, o individuo pode acumular experiências negativas, sensações repulsivas, desagradáveis em relação ao lugar, definidas como experiências topofóbicas.

Para a Geografia Humanista, lugar é o espaço que se torna familiar ao indivíduo, é o espaço vivido. Neste sentido o professor deve buscar compreender os processos mentais dos alunos envolvidos nas situações de ensino e aprendizagem, com intuito de construir conhecimentos de Geografia. Cavalcanti (1998) aponta que há uma necessidade de se considerar o saber e a realidade do aluno como referência para o estudo do espaço geográfico. O ensino de Geografia, não se deve pautar pela descrição e enumeração de dados, priorizando apenas aquelas visíveis e observáveis na sua aparência (na maioria das vezes impostos à "memória” dos alunos, sem real interesse por parte deles). Ao contrário, o ensino deve propiciar ao aluno a compreensão do espaço geográfico na sua concretude, nas suas contradições.

Morgado (2009) ressalta que a noção de real dos alunos resulta de suas experiências vividas e das múltiplas representações do real, elaboradas como imagens por diversos sujeitos coletivos e a partir das quais, fazem sua própria representação. Hoje, cada um de nós é como um ponto singular que em certa medida contém o mundo. Os lugares aparecem como o intermédio entre o mundo e o indivíduo. Como afirma Santos (1998) os lugares são mundiais, mas não há um espaço mundial, quem se globaliza são as pessoas e os lugares. Sendo assim é no lugar que se aprende o mundo e deve ser entendido em suas condições físicas e relações sociais que são complexas e ultrapassam as distancias (local/regional/mundial). Um lugar reproduz em si, com suas especificidades o global num determinado tempo e espaço.

Neste sentido Callai (2002, p. 84) ressalta sobre o estudo do lugar que: 
Estudá-lo é fundamental, pois ao mesmo tempo que o mundo é global, as coisas da vida, as relações sociais se concretizam nos lugares específicos. E como tal a compreensão da realidade do mundo atual se dá a partir dos novos significados que assume a dimensão do espaço local.

O conceito de lugar utilizado nos Parâmetros Curriculares Nacionais não difere da acepção empregada pela Geografia Humanista onde “A categoria lugar traduz os espaços com os quais as pessoas têm vínculos afetivos: uma praça onde se brinca desde criança, a janela de onde se vê a rua, o alto de uma colina de onde se avista a cidade. O lugar é onde estão as referências pessoais e o sistema de valores que direcionam as diferentes formas de perceber e constituir a paisagem e o espaço geográfico. É por intermédio dos lugares que se dá a comunicação entre homem e mundo” (BRASIL - PCN’s, 1998, p. 29).

Nesta perspectiva, nota-se que é de suma importância o estudo do bairro na escola, pois é nesta escala, a local, que o aluno compreendendo seu espaço de vivência, estará preparado para um posterior estudo global do espaço geográfico.

O estudo do bairro vai ao encontro da definição de Viero (2007, p. 27):

O bairro é o resultado de um conjunto de relações sociais que passa pela consciência histórica de permanecer a uma localidade. O conceito ultrapassa os limites administrativos, à medida que o grau de relações criadas entre as pessoas que vivenciam um mesmo cotidiano, de uma rua ou quarteirão, de praças ou igrejas, forma uma unidade espacial de profunda significância.

As atividades de desenhar a sala de aula, o bairro ou outro objeto próximo podem ser planejadas também considerando diferentes perspectivas, não apenas a horizontal, que é o modo como as crianças frequentemente desenham. É interessante desafiar os alunos a desenharem como se estivessem tendo uma visão vertical, ou seja, como se estivessem olhando de cima para baixo; ou ainda a desenharem tendo uma visão oblíqua, como se estivessem observando-os de cima e um pouco de lado (tal como a visão que as pessoas têm de uma cidade quando a olham da janela de um avião), não apenas os desenhos apresentados numa visão horizontal em que fornece uma visão limitada e parcial do lugar, mostrando somente a lateral de alguns objetos e omitindo outros. Esses desafios são oportunidades para que eles construam noções relacionadas às técnicas de projeção comumente utilizadas na cartografia e compreendam como ocorre a representação gráfica do espaço (CONSTRUIR NOTÍCIAS, 2009).

Com a aplicação do mapa mental, é possível identificar as facilidades e as dificuldades dos alunos referentes a esse tema. O aluno, ao elaborar seu mapa, se 
defrontará com uma série de desafios. O professor aplicador desses mapas, por meio de sua análise, perceberá nos mapas como o aluno se vê em meio à sociedade que vive, suas prioridades e fatos marcados em sua história, transmitidos através do empirismo demonstrado no mapa mental (BRUNINI, 2009).

Ao analisar desenhos deve-se levar em conta a individualidade da visão que um indivíduo tem de determinado lugar. Neste sentido Santos (2006, p. 206) afirma que:

\begin{abstract}
Os elementos desenhados estão ligados à cultura de cada indivíduo, permeados pelo jogo da imaginação. O desenho, tal como o todo, é construído de partes, e estas partes dão um rosto a cada representação gráfica. Ele demonstra uma enorme riqueza do potencial representativo gráfico, como construção e representação de conceitos.
\end{abstract}

Utilizar desenhos e mapas mentais faz com que o professor conheça o nível de espacialização dos alunos para delinear debates sobre a categoria lugar. Pois os desenhos e os mapas mentais são representações construídas baseadas na percepção dos lugares vividos, partindo de uma dada realidade.

Neste contexto, o presente trabalho visa desenvolver e avaliar uma seqüência didática para o estudo da categoria lugar com o auxílio de imagens de satélites, desenhos e mapas mentais. Também analisar o conhecimento espacial do espaço vivido dos alunos antes e depois do uso de imagem de satélite de alta resolução espacial. Além disso, desenvolver uma análise crítica dos alunos em relação aos problemas ambientais do bairro através da análise da imagem de satélite e conhecimento prévio do local de vivência.

\title{
MATERIAIS E MÉTODOS
}

As atividades empregadas foram baseadas em trabalhos anteriormente desenvolvidos por Móta (2007) e Corazza (2008). Durante a etapa de elaboração da sequência didática foi feita a seleção de imagens de satélite em arquivos digitais disponibilizados gratuitamente na Internet. Também foram utilizadas imagens do CDROM "O Sensoriamento Remoto como recurso didático no estudo do município de Santa Maria-RS” (SANTOS et. al., 2009). Com isso buscou-se empregar imagens que englobem o município de Santa Maria - RS, nas quais se possa trabalhar a divisão de bairros, dando ênfase ao Bairro Tancredo Neves, onde a escola que foi trabalhada está situada. As atividades desenvolvidas na escola tiveram duração de uma hora cada e estão descritas a seguir: 
Atividade 1 - Qual o lugar que você vive?

Esta atividade compreendeu o levantamento do entendimento de lugar dos alunos. Foi escrito no quadro as seguintes perguntas “Qual o lugar que você vive?” e “O que tem no seu lugar de vida?”. As perguntas foram respondidas em forma de desenhos. Após a confecção dos desenhos, procedeu-se uma breve discussão do que seria o lugar de vivência e qual nossa relação com o mesmo.

Atividade 2 - Mapa mental do Bairro Tancredo Neves

Nesta etapa, solicitou-se que cada aluno falasse um pouco sobre seu bairro, segundo o seu ponto de vista, ressaltando as características que consideram mais importantes. Após, foi distribuída uma folha de papel e escrito no quadro "Faça um mapa mental do Bairro Tancredo Neves”. Para a realização da atividade foi esclarecido aos alunos o que é um mapa mental e qual a sua utilidade.

Essa atividade teve o intuito de investigar o conhecimento espacial que cada aluno possui sobre o bairro, através de representações gráficas no papel de lugares conhecidos, remetidos de experiências no lugar em que vivem.

Atividade 3 - O Sensoriamento Remoto

Essa atividade consistiu na aproximação dos alunos com o sensoriamento remoto, dando ênfase nos princípios básicos, os produtos gerados por essa técnica e sua importância e utilidade. Para isso utlizou-se imagens de satélite de diferentes sensores e escalas. As imagens escolhidas (Quadro 2) para serem utilizadas nesta atividade foram as seguintes:

\begin{tabular}{|c|c|}
\hline Imagem de satellite & Fonte \\
\hline $\begin{array}{l}\text { Mapa Mundi-Mosaico de Imagens } \\
\text { do Satélite NOAA/AVHRR (National } \\
\text { Oceanic Atmospheric Administration/ } \\
\text { Advanced Very High Resolution } \\
\text { Radiometen) }\end{array}$ & $\begin{array}{llll}\text { Produzida pelo projeto } & \text { EDUCA } & \text { SeRe } & \text { III, } \\
\text { pertencente ao Instituto Nacional de } & \text { Pesquisas } \\
\text { Espaciais } & \text { (INPE) e disponível em } & \text { em } \\
\text { www.inpe.br/unidades/cep/atividadescep/educasere }\end{array}$ \\
\hline $\begin{array}{l}\text { Globo Terrestre com vista das } \\
\text { Américas - Imagem de Satélite } \\
\text { GOES-E (Geostationary Operational } \\
\text { Environmental Satellites) }\end{array}$ & $\begin{array}{llll}\text { Produzida pelo projeto } & \text { EDUCA SeRe III, } \\
\text { pertencente ao Instituto Nacional de Pesquisas } \\
\text { Espaciais } & \text { (INPE) e disponível em } \\
\text { www.inpe.br/unidades/cep/atividadescep/educasere }\end{array}$ \\
\hline Imagens meteorológicas da & Produzidas pelo satélite meteorológico GOES em 13 \\
\hline
\end{tabular}




\begin{tabular}{|l|l|}
\hline $\begin{array}{l}\text { América do Sul e da Região } \\
\text { Sul do Brasil }\end{array}$ & $\begin{array}{l}\text { de novembro de 2007 e disponibilizadas no site do } \\
\text { Centro de Previsão de Tempo e Estudos Climáticos } \\
\text { (CPTEC) do INPE: http://satelite.cptec.inpe.br/home }\end{array}$ \\
\hline $\begin{array}{l}\text { Mosaico de imagens CBERS } \\
\text { (China-Brazil Earth-Resources } \\
\text { Satellite) - Brasil }\end{array}$ & $\begin{array}{l}\text { Produzida pelo projeto EDUCA SeRe III, } \\
\text { pertencente ao Instituto Nacional de Pesquisas } \\
\text { Espaciais (INPE) e disponível em } \\
\text { www.inpe.br/unidades/cep/atividadescep/educasere }\end{array}$ \\
\hline $\begin{array}{l}\text { Mosaico de imagens CBERS - } \\
\text { Estado do Rio Grande do Sul }\end{array}$ & $\begin{array}{l}\text { Produzida pelo projeto EDUCA SeRe III, } \\
\text { pertencente ao Instituto Nacional de Pesquisas } \\
\text { Espaciais (INPE) e disponível em } \\
\text { www.inpe.br/unidades/cep/atividadescep/educasere }\end{array}$ \\
\hline $\begin{array}{l}\text { Carta imagem de Santa } \\
\text { Maria, RS - Brasil }\end{array}$ & $\begin{array}{l}\text { Produzida pelo projeto EDUCA SeRe III, } \\
\text { pertencente ao Instituto Nacional de Pesquisas } \\
\text { Espaciais (INPE) e disponível em } \\
\text { www.inpe.br/unidades/cep/atividadescep/educasere }\end{array}$ \\
\hline $\begin{array}{l}\text { Imagem de Satélite de Santa } \\
\text { Maria no Brasil }\end{array}$ & $\begin{array}{l}\text { Imagem Ikonos (alta resolução) e Landsat (baixa } \\
\text { resolução), retiradas do Google Earth. }\end{array}$ \\
\hline $\begin{array}{l}\text { Imagem de Satélite de Santa } \\
\text { Maria no Rio Grande do Sul }\end{array}$ & $\begin{array}{l}\text { Imagem Ikonos (alta resolução) e Landsat (baixa } \\
\text { resolução), retiradas do Google Earth. }\end{array}$ \\
\hline $\begin{array}{l}\text { Imagem de Satélite de Santa } \\
\text { Maria - RS }\end{array}$ & $\begin{array}{l}\text { Imagem Ikonos (alta resolução) e Landsat (baixa } \\
\text { resolução), retiradas do Google Earth. }\end{array}$ \\
\hline
\end{tabular}

Quadro 2 - Imagens de satélite selecionadas para realização da atividade sobre sensoriamento remoto.

As imagens de satélite impressas, o globo terrestre e uma réplica em dobradura do Satélite Sino-Brasileiro de Recurso Terrestres (CBERS) feita em dobradura (disponível em www.inpe.br/unidades/cep/atividadescep/educasere) foram colocadas em uma classe em frente aos alunos. Após, pediu-se que em pequenos grupos, os alunos se dirigissem até a classe e observassem as imagens, o globo e a réplica, buscando identificar que materiais estavam observando, quais as áreas apresentadas nas imagens e que tipos de relação os objetos possuíam.

Na seqüência solicitou-se que os alunos retornassem às suas classes e que expusessem de forma oral as constatações feitas a partir da observação das imagens. Através disso deu-se início a explanação dos princípios do sensoriamento remoto, explicando o processo de obtenção de uma imagem enfocando a forma como uma imagem é produzida e qual a utilidade das imagens para os dias atuais. Os alunos foram questionados se conheciam alguma utilidade das imagens de satélite, contribuindo com seus conhecimentos prévios, mostrando que o sensoriamento remoto está presente na vida de cada um. 
Atividade 4 - A imagem de satélite do Núcleo Habitacional Tancredo Neves

Englobou uma atividade prática, em que se deu início com uma breve explicação de como visualizar e extrair as informações das imagens de satélite, orientando os alunos sobre os elementos de interpretação. A etapa posterior consistiu na entrega de uma imagem do satélite Ikonos do Núcleo Habitacional Tancredo Neves (Figura 1), de uma folha de papel vegetal e um clips para cada aluno. Pediu-se para que os alunos fixassem com o auxílio de clips o papel vegetal sobre a imagem e com um lápis traçassem os elementos geográficos (Quadro 3), solicitados na folha de instrução entregue juntamente com a imagem, identificando cada elemento copiado com o seu respectivo número. Os alunos foram orientados a escreverem num dos cantos do papel vegetal o nome e idade, além do número do elemento geográfico que não conseguiram identificar.

\begin{tabular}{|c|l|}
\hline Número & Elemento geográfico \\
\hline $\mathbf{1}$ & Os limites da área urbana do Bairro Tancredo Neves \\
\hline $\mathbf{2}$ & As áreas de mata \\
\hline $\mathbf{3}$ & Uma área com campo \\
\hline $\mathbf{4}$ & Drenagens \\
\hline $\mathbf{5}$ & Uma área que apresente casas \\
\hline $\mathbf{6}$ & Avenida principal \\
\hline $\mathbf{7}$ & Uma rua pavimentada (asfaltada ou com calçamento) \\
\hline $\mathbf{8}$ & Uma rua não pavimentada (estradas) \\
\hline $\mathbf{9}$ & Um círculo sobre a localização da escola \\
\hline $\mathbf{1 0}$ & Outros lugares conhecidos que você identifica na imagem \\
\hline $\mathbf{1 1}$ & Prováveis locais de degradação ambiental no bairro \\
\hline
\end{tabular}

Quadro 3 - Elementos geográficos solicitados aos alunos para identificação na imagem de satélite. 


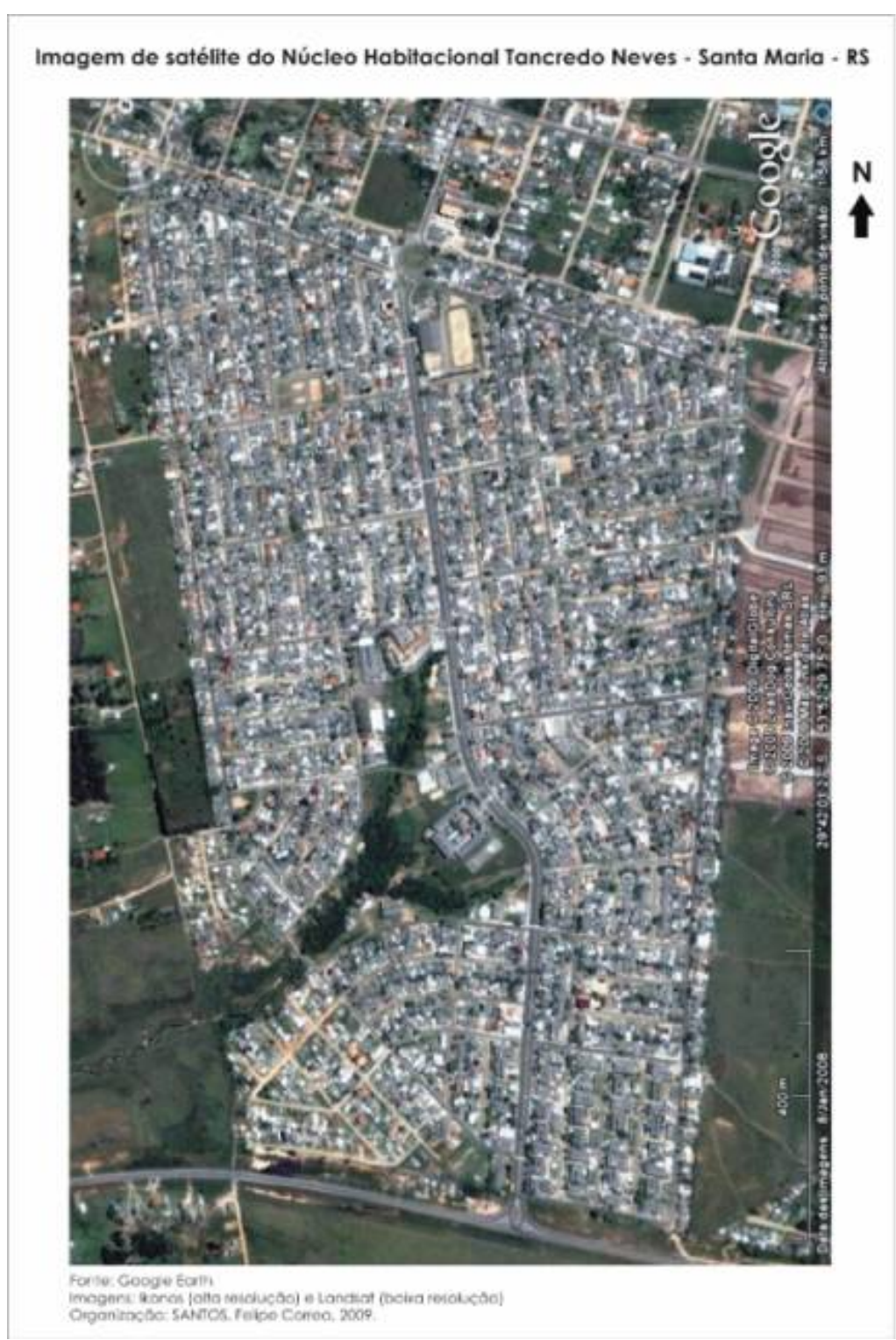

Figura 1 - Imagem de satélite do Núcleo Habitacional Tancredo Neves, Santa Maria, RS.

No final desta atividade deu-se ênfase na discussão do item 11, dos prováveis locais de degradação ambiental no bairro. Por haver apenas mais uma aula disponível para aplicação da seqüência didática, não foi possível uma visita nos locais indicados, assim os alunos levaram a imagem para casa, para poderem acompanhar estes lugares e fazerem um maior reconhecimento dos diversos elementos da imagem no seu caminho da escola para casa, e poderem fazer breves comentários em um próximo encontro. 
Atividade 5 - Mapa mental do Bairro Tancredo Neves após a utilização da imagem de satélite do bairro

Essa atividade teve início com um breve comentário sobre a atividade da aula passada, o uso da imagem de satélite do bairro. Solicitou-se que os alunos comentassem sobre as hipóteses de problemas ambientais após a visualização da imagem e a verificação por alguns deles da real ocorrência dos mesmos.

Em um segundo momento, após a atividade com a imagem de satélite do bairro e os alunos já estarem cientes do que é um mapa mental, para finalizar as atividades, foi distribuída uma folha de papel e solicitou-se que cada aluno fizesse novamente um mapa mental do bairro, ressaltando as características que consideram mais importantes e lugares conhecidos. Essa atividade teve o intuito de investigar se houve uma expansão no conhecimento espacial que cada aluno possui sobre o bairro após a discussão sobre o bairro e principalmente a utilização da imagem de satélite.

Após as práticas em sala de aula foram realizadas as conclusões do trabalho, através das observações em sala de aula e do material produzido pelos alunos. Foi verificada a interpretação da imagem de satélite do bairro e avaliado as dificuldades para o trabalho, levando em consideração os elementos identificados e a análise crítica em relação à questão ambiental do Bairro Tancredo Neves. Assim, pode-se analisar a compreensão do espaço vivido dos alunos antes e depois do uso de imagem através da comparação dos mapas mentais confeccionados por eles. As conclusões do trabalho foram baseadas nas constatações extraídas em sala de aula, adequando-se aos objetivos propostos.

\section{RESULTADOS}

A aplicação da proposta didática desenvolvida em cinco aulas ocorreu em uma turma de 25 alunos de $5^{\text {a }}$ série do ensino fundamental (Turma 54), com média de idade de 10,8 anos, da Escola Básica Estadual Dr. Paulo Devanier Lauda, localizada no Bairro Tancredo Neves, município de Santa Maria - Rio Grande do Sul, no segundo trimestre de 2009. Apresenta-se a seguir os resultados da seqüência didática aplicada: 
Atividade 1 - Qual o lugar que você vive?

Em relação às perguntas “Qual o lugar que você vive?” e “O que tem no seu lugar de vida?” 64\% dos alunos, lugar de vida é a casa e para 36\% deles, seu lugar de vida é a casa e sua localização espacial. Nos desenhos, os alunos representam seu lugar de vida com muitos detalhes, como a casa com a janela aberta, as roupas secando, uma árvore junto a casa, reflexo de sua forte ligação com o local, como mostra a Figura 2.

O lar é um lugar íntimo. Pensamos na casa como lar e lugar, mas as imagens atraentes do passado são evocadas não tanto pela totalidade do prédio, que somente pode ser visto, como pelos seus elementos e mobiliário (TUAN, 1983).

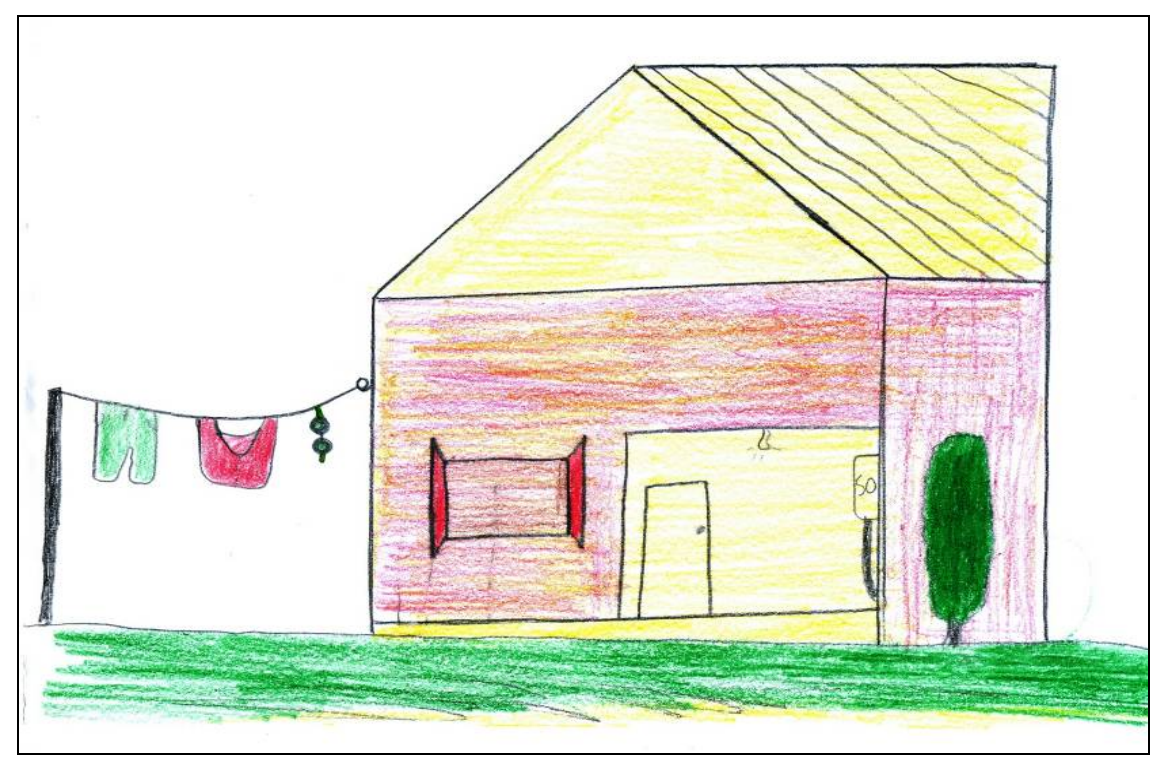

Figura 2 - Lugar de vivência: a casa.

Nos desenhos que os alunos representaram a casa e sua localização espacial, nota-se que eles indicaram o local onde a casa está inserida, seja uma rua ou o bairro, ainda com casas vizinhas a sua. Na Figura 3, o aluno indicou que seu lugar de vida é em uma casa situada na Avenida Paulo Lauda e representou o trafego de ônibus que ocorre nesta via. 


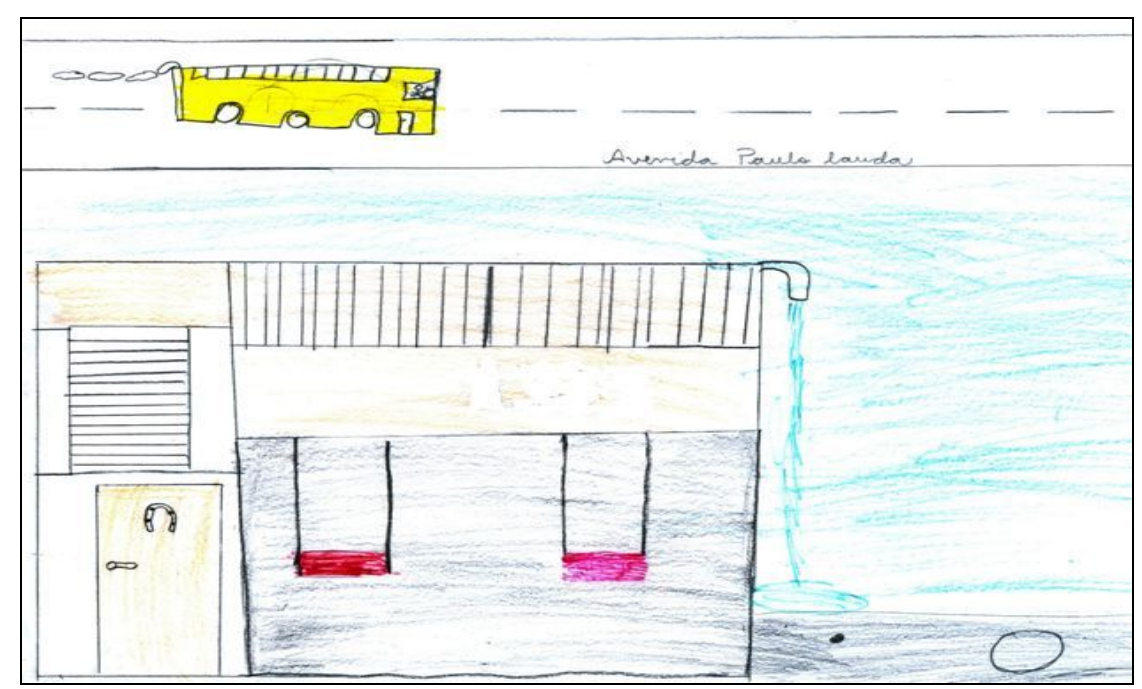

Figura 3 - Lugar de vivência: a casa e sua localização.

O Gráfico 1 representa os elementos que remetem ao lugar de vida dos alunos representados nos desenhos. Todos os alunos representaram no mínimo uma casa em seu lugar de vivência. 77,30\% dos alunos representaram elementos da natureza em seus desenhos, como árvores, gramados, flores, nuvens e o sol.

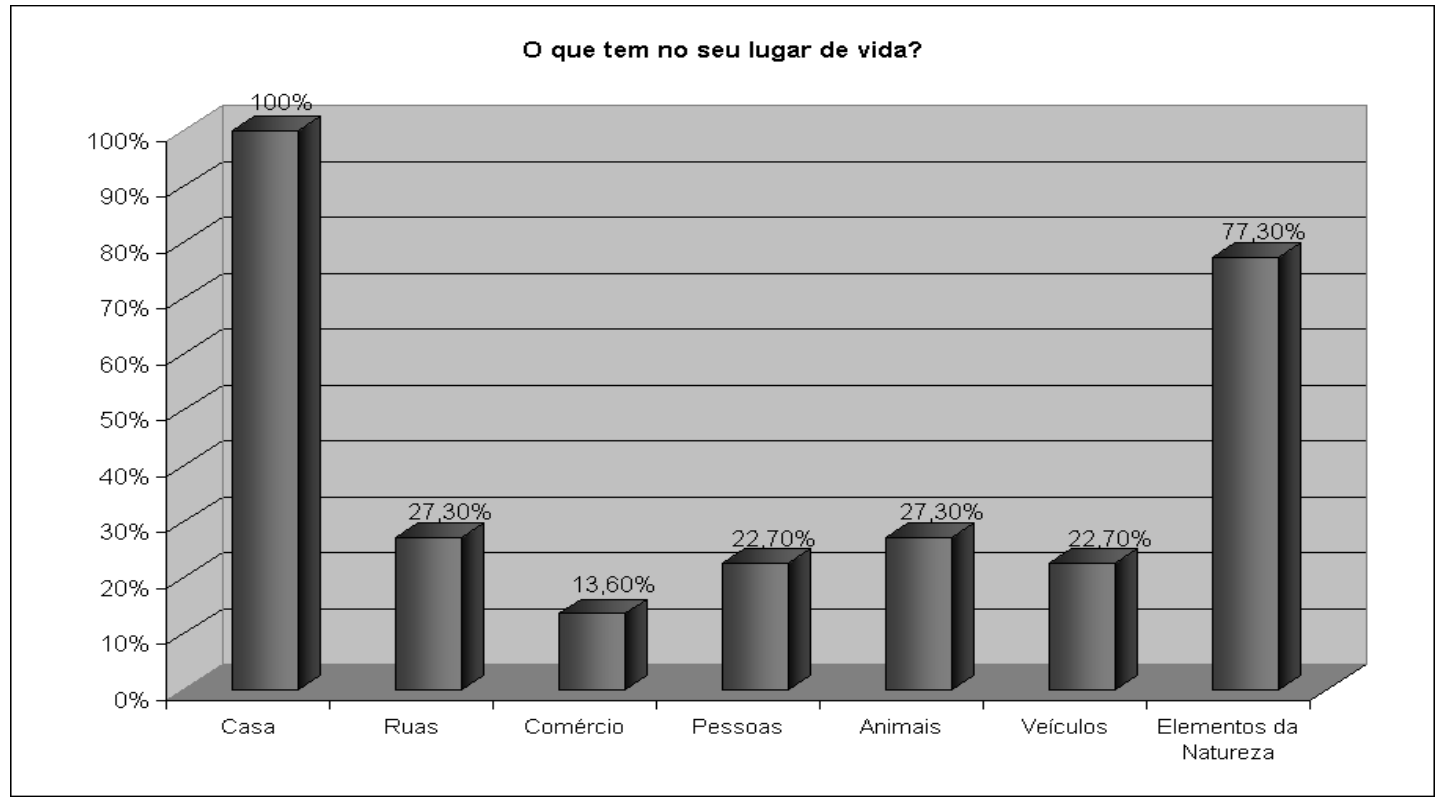

Gráfico 1 - Respostas da questão “O que tem no seu lugar de vida?

Conforme a Figura 4, o aluno representou sua casa ao lado de casas vizinhas, a rua com tráfego de automóveis, áreas de lazer como o campo de futebol e interação entre pessoas e animais, todos elementos de sua vivência. Nota-se a representação de 
elementos da natureza, como árvores, plantas e flores, porém a ausência de grama é constatada, sendo típico de algumas áreas urbanas.

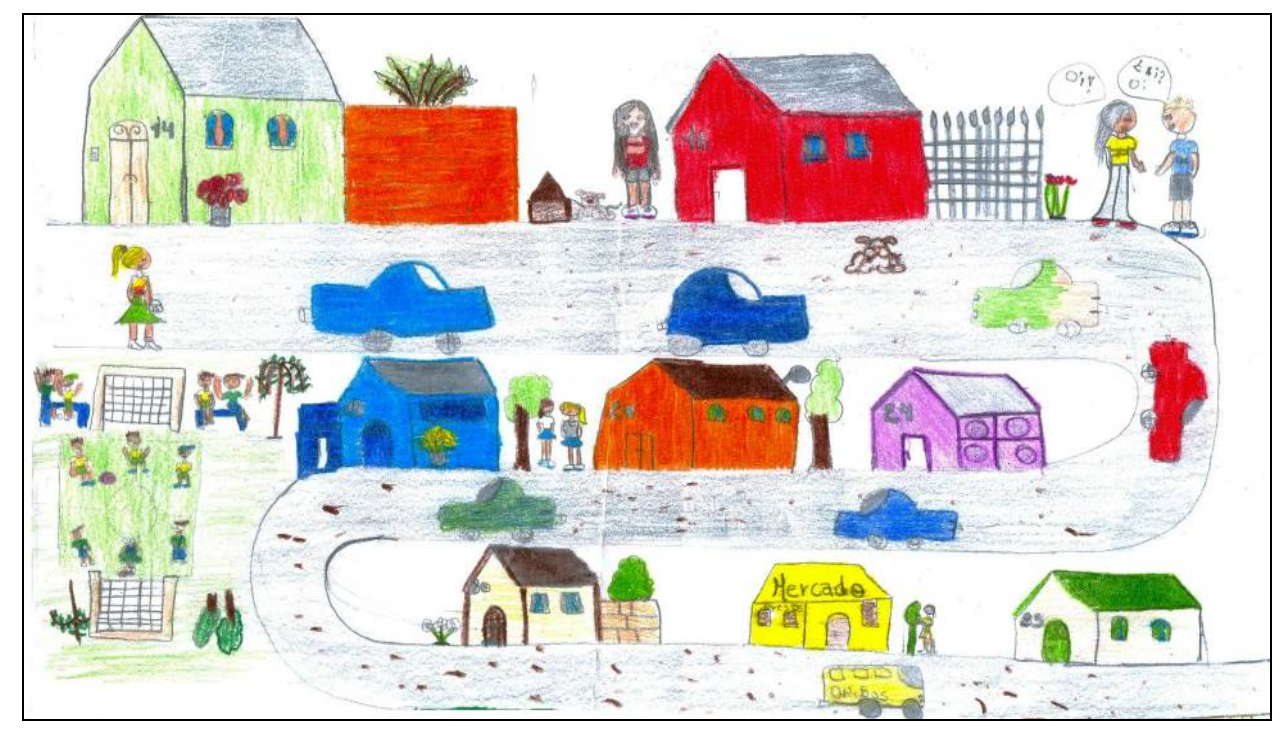

Figura 4 - Elementos do lugar de vivência.

Os alunos que usam cores vivas, representam o sol e as nuvens em seus desenhos, pode estar demostrando um elo afetivo com o lugar onde vive, maior que alunos que representaram seu local de vivência usando traços sem cores e poucas representações. Como se observa na Figura 5, em que o aluno representou seu local de vivência com poucos traços, sem elementos da natureza, somente com a casa e as grades que a cerca.

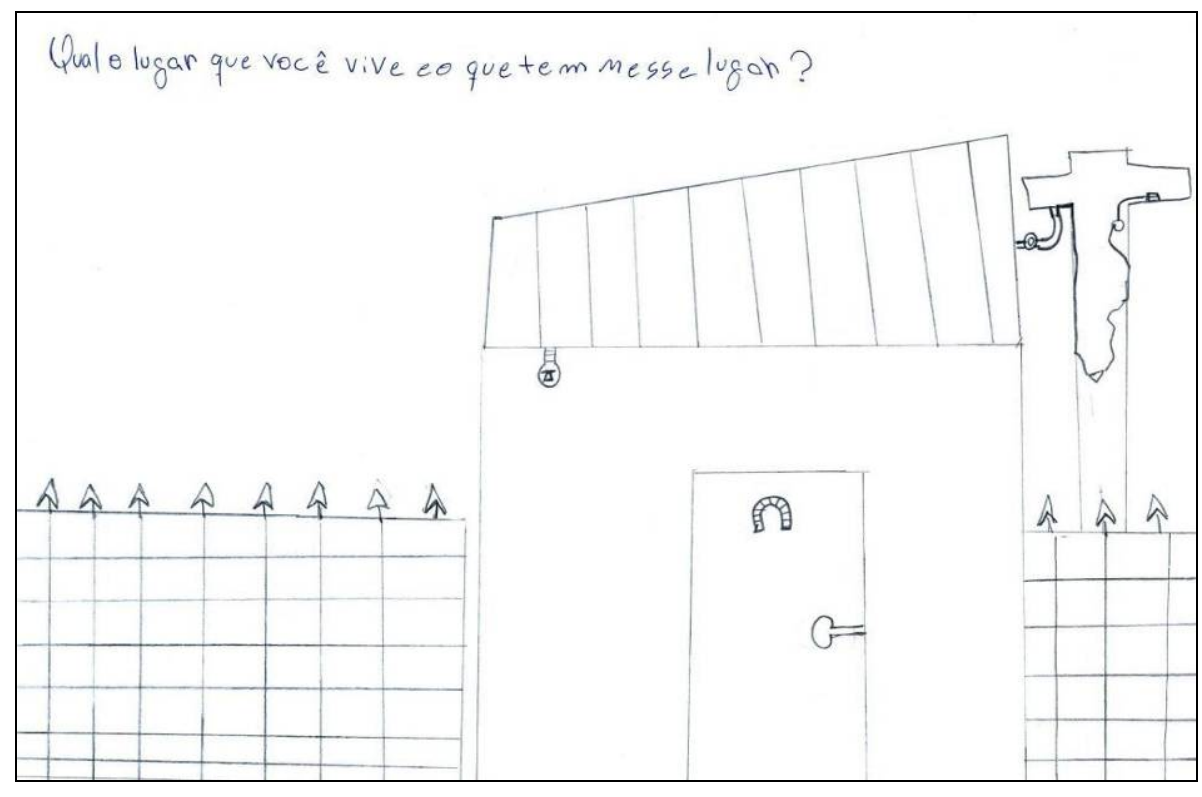

Figura 5 - Casa e grades. 
Conforme a Figura 6 observa-se que os alunos também representaram o comércio (13,60\%) existente em seu local de vivência, como supermercados, bares, açougues e lojas, representando estes locais, onde eles tem mais contato. Isto vai ao encontro das considerações de Tuan (1983), em que as criancas mostram pouca preocupação com o bairro como uma entidade física e social; seus interesses se restringem unicamente à própria rua e às lojas que freqüentavam.

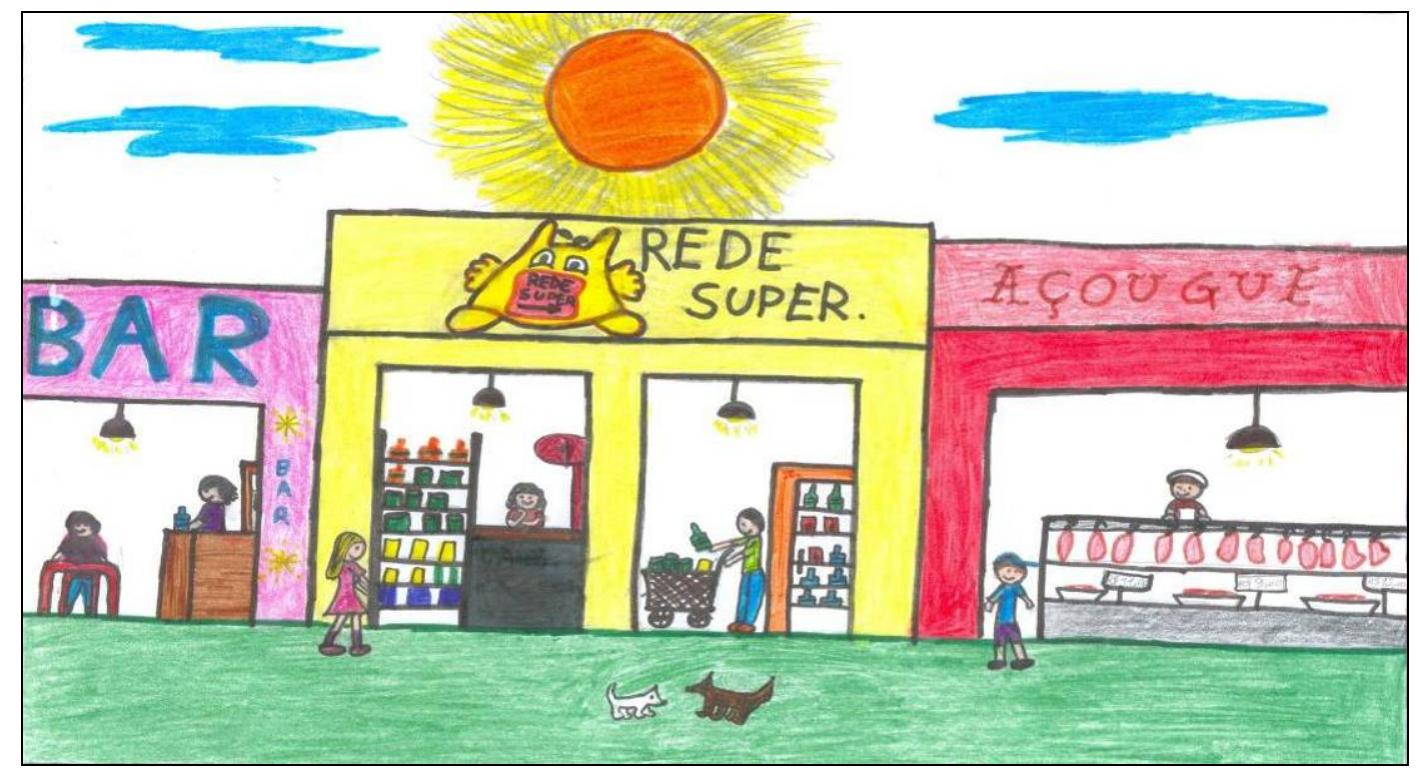

Figura 6 - O comércio local.

Atividade 3 - O Sensoriamento Remoto

Esta atividade foi de suma importância para a realização do trabalho com imagens de satélite, pois através de uma breve explicação sobre o que é o sensoriamento remoto, de forma simplificada, os alunos puderam participar ativamente da atividade, constituindo-se em um ponto forte para um melhor entendimento.

Os alunos visualizaram as diferentes imagens de satélite, o globo terrestre e a réplica de um satélite e foram questionados sobre qual a relação existente sobre aqueles objetos expostos. Houve muitos questionamentos sobre o que era a réplica, após a aproximação da réplica ao globo, alguns alunos apontaram como uma possível câmera fotográfica. A partir desta constatação, revelou-se ser um satélite e a partir dele que eram geradas as diferentes imagens expostas. 
A palavra satélite soou familiar aos alunos e alguns apontaram que já tinham ouvido falar em satélites que geravam imagens para a televisão. Distinguiram-se os tipos de satélite e que, apesar do nome, não eram de mesma utilidade. Os satélites que estava sendo estudado eram os imageadores, que geravam imagens da superfície terrestre pra diversos fins.

Os alunos se mostraram muito interessados sobre o assunto e apontaram que em diversos telejornais apareciam imagens como as trabalhadas em sala de aula, que utilizavam para localizar determinados locais de uma notícia e na previsão do tempo, sobre as quais localizavam locais e ocorrências de determinados fenômenos meteorológicos.

Aproveitou-se a oportunidade para esclarecer algumas noções cartográficas no que se refere à visão vertical referente às imagens de satélite. Para isso os alunos foram orientados a visualizar as imagens de satélite na mesa, para obter uma melhor visualização na vertical, na mesma ótica de visão que o satélite registra a imagem.

A partir desta atividade pode-se utilizar do conhecimento prévio dos alunos, gerando uma grande participação e interesse. Gerando uma maior motivação para a próxima atividade, em que utilizaram uma imagem de satélite do bairro.

Atividade 4 - A imagem de satélite do Bairro Tancredo Neves

A partir desta atividade, os alunos realizaram a identificação dos elementos geográficos sobre a imagem de satélite do Bairro Tancredo Neves, através da visualização da imagem e a utilização de seu conhecimento prévio, com o intuito de expandir o conhecimento espacial do seu lugar de vivência. A Tabela 1 apresenta os resultados obtidos, seguidos da análise dos mesmos:

Tabela 1 - Resultados obtidos para cada elemento geográfico identificado na imagem de satélite.

\begin{tabular}{|l|c|c|c|}
\cline { 2 - 4 } \multicolumn{1}{c|}{} & \multicolumn{3}{c|}{ Respostas } \\
\hline Elemento geográfico & $\begin{array}{c}\text { Adequadas } \\
(\mathbf{\%})\end{array}$ & $\begin{array}{c}\text { Inadequadas } \\
(\mathbf{\%})\end{array}$ & $\begin{array}{c}\text { Em Branco } \\
\text { (\%) }\end{array}$ \\
\hline 1. Os limites da área urbana do Bairro Tancredo Neves & 80 & 12 & 8 \\
\hline 2. As áreas de mata & 72 & 24 & 4 \\
\hline 3. Uma área com campo & 60 & 8 & 32 \\
\hline 4. Drenagens & 56 & 4 & 40 \\
\hline 5. Uma área que apresente casas & 96 & 0 & 4 \\
\hline
\end{tabular}




\begin{tabular}{|l|l|l|l|}
\hline 6. Avenida principal & 88 & 0 & 12 \\
\hline 7. Uma rua pavimentada (asfaltada ou com calçamento) & 52 & 0 & 48 \\
\hline 8. Uma rua não pavimentada (estradas) & 40 & 0 & 60 \\
\hline 9. Um círculo sobre a localização da escola & 80 & 0 & 20 \\
\hline
\end{tabular}

O primeiro item solicitado aos alunos, os limites da área urbana do Bairro Tancredo Neves, obteve-se $80 \%$ de indicações adequadas. O índice elevado de acertos deve-se principalmente na diferença entre cor e textura da área urbana em relação às áreas rurais apresentadas no restante da imagem. Isso também explica o fato de ocorrem 12 \% de indicações inadequadas em que os alunos incluíram partes do bairro vizinho (Parque Pinheiro Machado) na delimitação.

Nos elementos “áreas de mata” e "uma área de campo”, os alunos apresentaram porcentagens de identificações adequadas de $72 \%$ e $60 \%$ respectivamente. Houve uma porcentagem de $24 \%$ de indicações inadequadas de áreas de mata e 32\% dos alunos deixaram em branco as áreas de campo, devido a semelhança de cor destes itens, levando alguns alunos a errarem ou optarem deixar em branco no papel vegetal.

No elemento solicitado “drenagens”, 56\% dos alunos responderam adequadamente e $40 \%$ optaram por deixar em branco no papel vegetal. O motivo da grande dificuldade dos alunos em visualizar a drenagem na imagem de satélite é pela presença de mata ciliar no seu entorno, dificultando a visualização da drenagem propriamente dita, pois alguns alunos marcaram inadequadamente ao indicarem a drenagem até onde ela estava visível na imagem, não indicando quando aparecia a mata ciliar.

De acordo com estes dados, constata-se a necessidade de o professor revisar periodicamente estes elementos do espaço geográfico que está tão próximo da vivência do aluno, pois este afluente que deveria ser destacado na imagem localiza-se próximo à escola, podendo ser explorado em sala de aula, a importância e preservação das matas ciliares e dos recursos hídricos nos locais próximos aos alunos e à escola.

Um elevado número de alunos indicaram corretamente uma área que contenha casas na imagem de satélite. A grande facilidade de identificação deste elemento, por ser uma imagem de alta resolução é pela cor e textura das áreas de moradia, e pela anterior identificação dos limites do bairro em que os alunos já constataram a presença de casas. 
No que se refere ao item "Avenida principal”, os alunos tiveram facilidade em indicar adequadamente sua localização, por ser uma rua mais larga que as demais ruas do bairro, facilitando a visualização na imagem. Destaca-se que a Avenida Paulo Lauda, foi de grande lembrança pelos alunos ao retratarem o bairro em seus desenhos e mapas mentais em outras atividades, pois a partir dela que ocorre o acesso às demais ruas e pela grande parte da área comercial existente no bairro estar situado nela, remetendo ao conhecimento dos alunos pela sua vivência neste local.

Quanto aos itens “uma rua pavimentada (asfaltada ou com calçamento)” e "uma rua não pavimentada”, os índices de respostas adequadas de ambos foi baixo e elevada porcentagem de respostas deixadas em branco. Estas porcentagens devem-se principalmente à dificuldade de distinção entre uma via pavimentada e uma via não pavimentada, embora ambos os itens estejam de fácil visualização nas imagens de satélite.

Os alunos identificaram com facilidade a localização da escola, por escola ser um prédio de grande porte, o maior do bairro e por estar situada na avenida principal do bairro, que foi facilmente indicada anteriormente. Os alunos também possuem facilidade em localizar outros locais e estes estão geralmente próximos a escola e a Avenida Paulo Lauda, como o posto de saúde, o Centro Comercial Tancredo Neves, o Ginásio Poliesportivo Oréco, supermercados, etc. Constata-se que sejam locais de familiaridade para os alunos, de conhecida localização por experiência vivenciadas neles em seu dia-a-dia, tanto por freqüentarem estes locais ou por passarem em seu trajeto diário até a escola.

Os principais problemas ambientais existentes no Bairro Tancredo Neves indicados pelos alunos foram: lixo e dejetos nos afluentes, presença de animais e desmoronamento das margens do Arroio Ferreira, localizado ao lado e atrás da escola. Destaca-se que por motivos de curto tempo para visualização destes locais e por serem conhecidos por toda a turma, os alunos em aula posterior a discussão, confirmaram a real a ocorrência destes problemas ambientais e três alunos trouxeram fotos destes locais tiradas por câmera de um telefone celular.

Com as fotos transferidas para um computador notebook, a turma pode visualizá-las e disseram estarem cientes da situarão dos dois locais indicados. Apontaram da importância de informar a população de não jogar lixo perto do córrego e da escola (Figura 7), mesmo que já apresente uma placa informando da proibição de colocar lixo no local (Figura 8). 


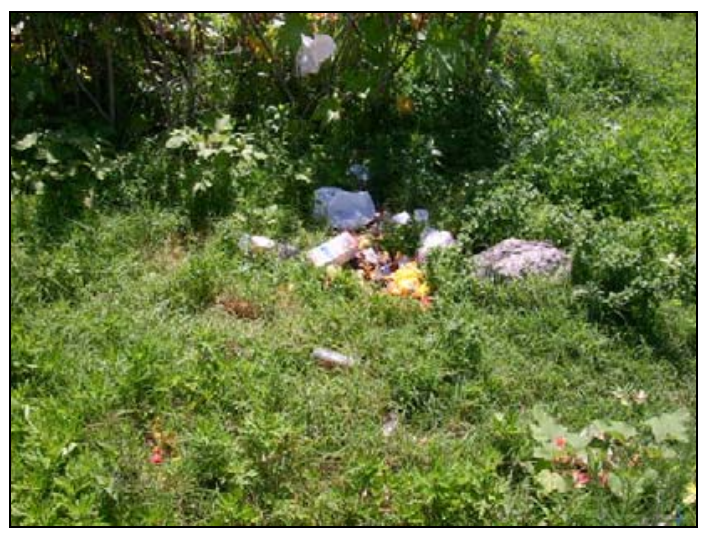

Figura 7 - Lixo perto do córrego e da escola.

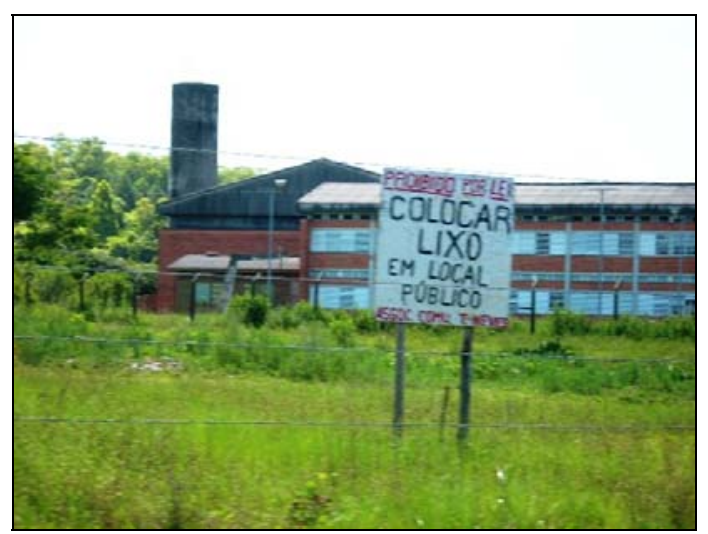

Figura 8 - Placa informando a proibição de colocar lixo no local.

No córrego localizado nos fundos da escola, os alunos confirmaram também a presença de lixo nas suas margens (Figura 9). Os alunos comentaram o desmoronamento da margem do córrego (Figura 10) e acreditam ocorrer pelo fato de a população próxima pôr animais (cavalos e vacas) pastarem no local (Figura 11).

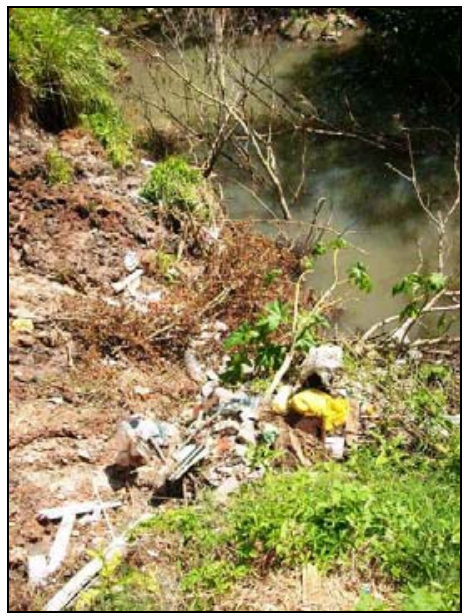

Figura 9 - Lixo no córrego próximo à escola.

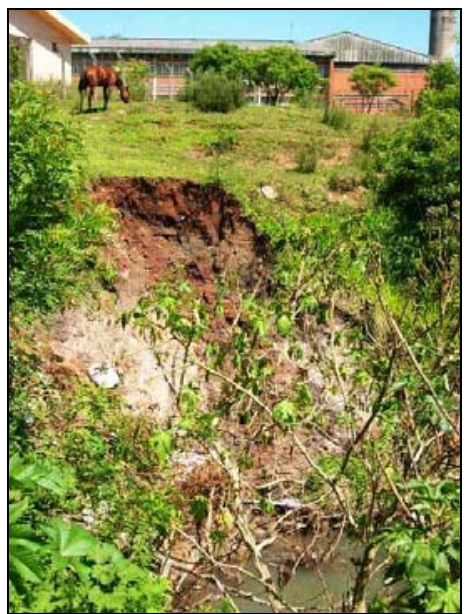

Figura 10 - Desmoronamento das margens do córrego.

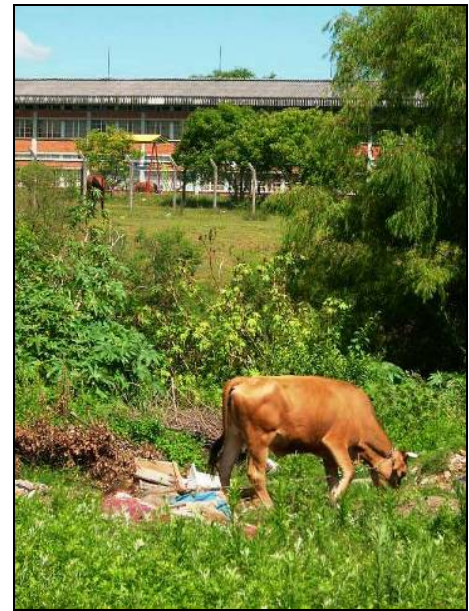

Figura 11 - Animais pastando próximo às margens do córrego.

Nota-se que as indicações de problemas ambientais foram de áreas próximas à escola, por serem de fácil visualização pelos alunos diariamente. Através desta atividade estimulou-se os alunos a análise espacial relacionada com os problemas ambientais do espaço vivido.

Atividade 2 e Atividade 5 - Mapa mental do Bairro Tancredo Neves antes e após a utilização da imagem de satélite do bairro

Conforme descrito na metodologia a atividade 2 consistiu na confecção de um mapa mental do bairro, tendo como objetivo investigar o conhecimento que o aluno possui de seu 
lugar de vida. Através da análise dos mapas mentais pode-se observar que grande parte os alunos representaram uma área reduzida, apenas com vizinhanças e quarteirões próximos à sua casa. Os alunos representaram também lugares conhecidos, geralmente o comércio existente na avenida principal do bairro, reflexo de experiências nesses lugares.

Os mapas mentais da atividade 2 serviram para uma comparação com os mapas mentais novamente confeccionados pelos alunos na atividade 5, esta realizada após as atividades que envolvem o sensoriamento remoto e o uso da imagem de satélite do Bairro Tancredo Neves. Constatou-se que 76\% dos alunos apresentaram melhoras em seus mapas mentais e $24 \%$ não apresentaram melhoras, pois fizeram apresentações de mesmo nível do primeiro mapa mental confeccionado. Destaca-se que a média de idade do primeiro grupo de alunos (os que obtiveram melhorias nos seus mapas mentais) era de 11 anos e o segundo grupo era de 10,3 anos. O resultado mostra que há dois grupos de alunos em fases cognitivas distintas. A idade do aluno deve ser considerada quando se utiliza produtos de sensoriamento remoto, pois nesta faixa etária o aluno encontra-se em transição de suas fases cognitivas.

Após a realização da atividade de interpretação da imagem de satélite do bairro, os alunos apresentaram melhores representações em seus mapas mentais. Como o caso aluno 1 que representou o bairro com elementos espaciais mais organizados no segundo mapa (Figura 12) em relação ao primeiro (Figura 11), resultante da visualização da imagem de satélite em uma visão vertical. Nota-se a diferença na organização dos quarteirões e do formato das ruas e da avenida principal e o segundo mapa estar mais de acordo com a realidade dos elementos representados.

Outra contribuição da utilização da imagem também está relacionada a visão vertical do bairro que os alunos puderam observar. Nota-se que o primeiro mapa mental (Figura 13) do aluno 2, o bairro está representado em uma visão horizontal, mesmo que antes da confecção ser orientado sobre a visão vertical. Esta dificuldade de compreensão sobre as visões da confecção de mapas foi sanada através da visualização das imagens de satélite, que proporciona ao aluno uma visão vertical, a qual o aluno não esta acostumado a visualizar no seu cotidiano. Após ter trabalhado com a imagem de satélite do bairro, o aluno 2 representou em seu segundo mapa mental (Figura 14) uma área semelhante a anterior, porém com os elementos apresentados em uma visão vertical e a forma das ruas com curvas, condizendo com a realidade, pois anteriormente havia representados todas as ruas em linha reta. $\mathrm{O}$ aluno também representou uma área verde, $\mathrm{o}$ afluente do Arroio Ferreira e a mata ciliar existente ao lado da escola, que foi trabalhado na imagem de satélite e tema na discussão sobre os problemas ambientais do bairro. 


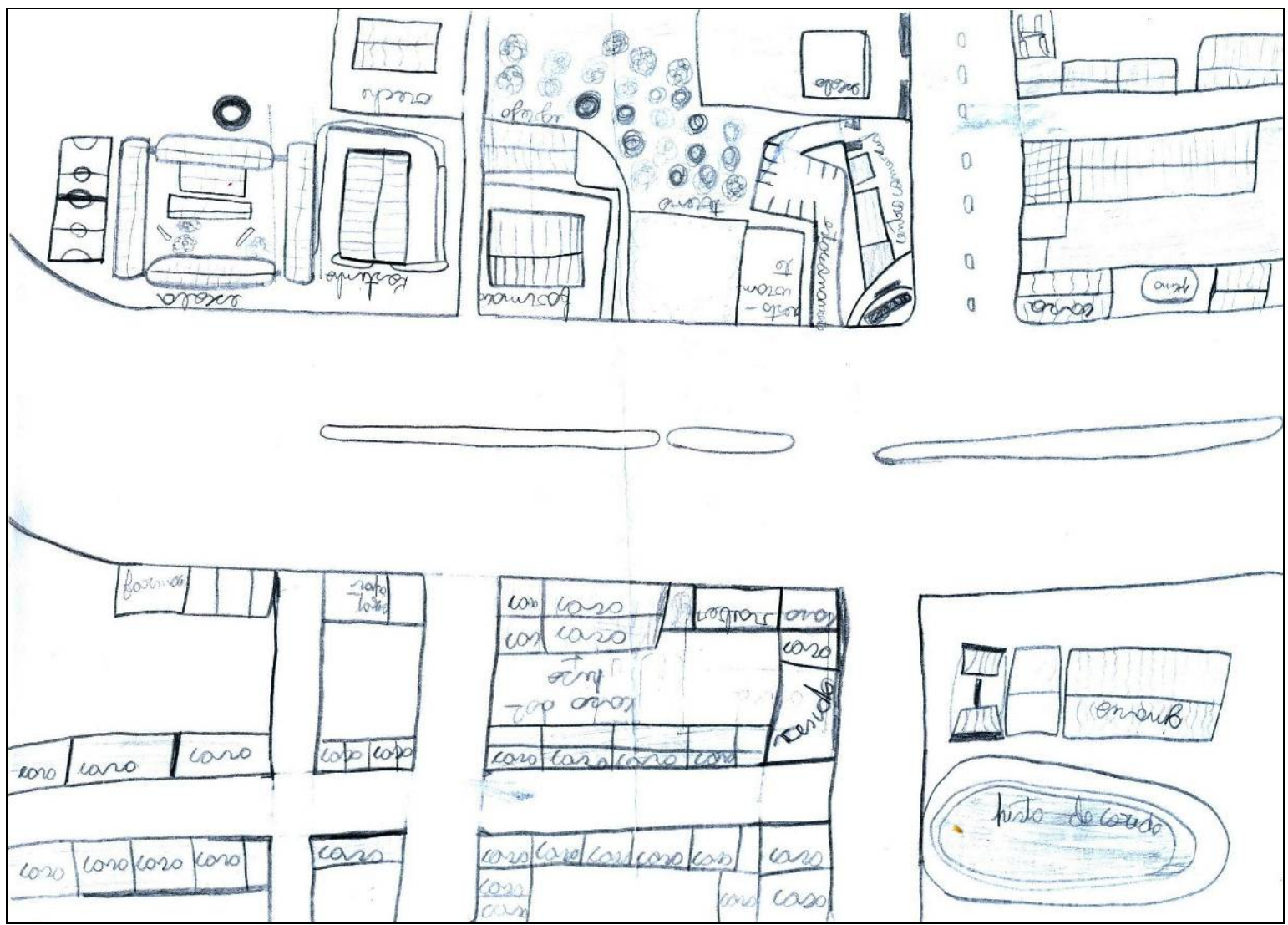

Figura 11 - Mapa mental do aluno 1 ANTES da utilização da imagem de satélite do bairro.

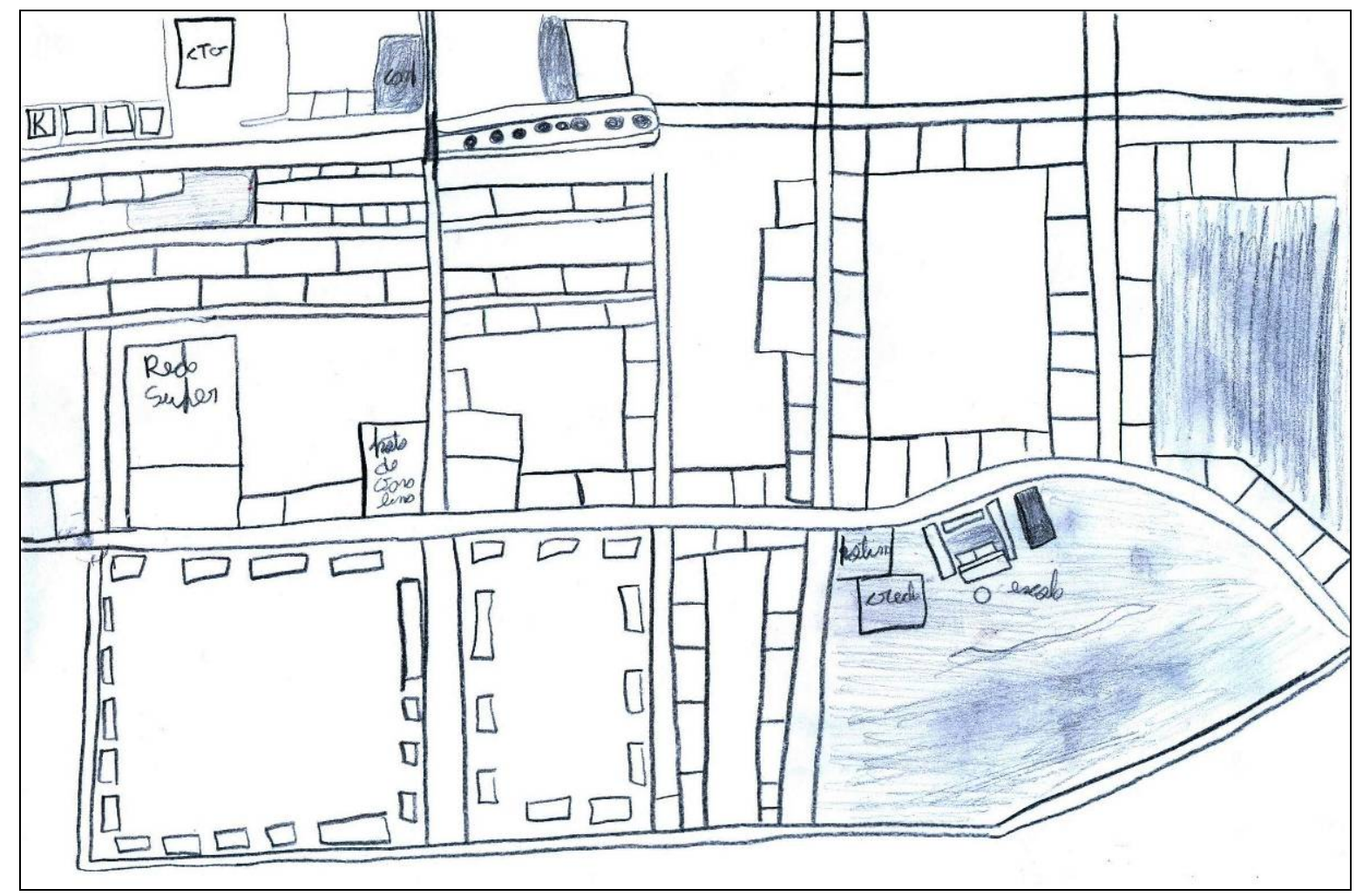

Figura 12 - Mapa mental do aluno 1 APÓS a utilização da imagem de satélite do bairro. 


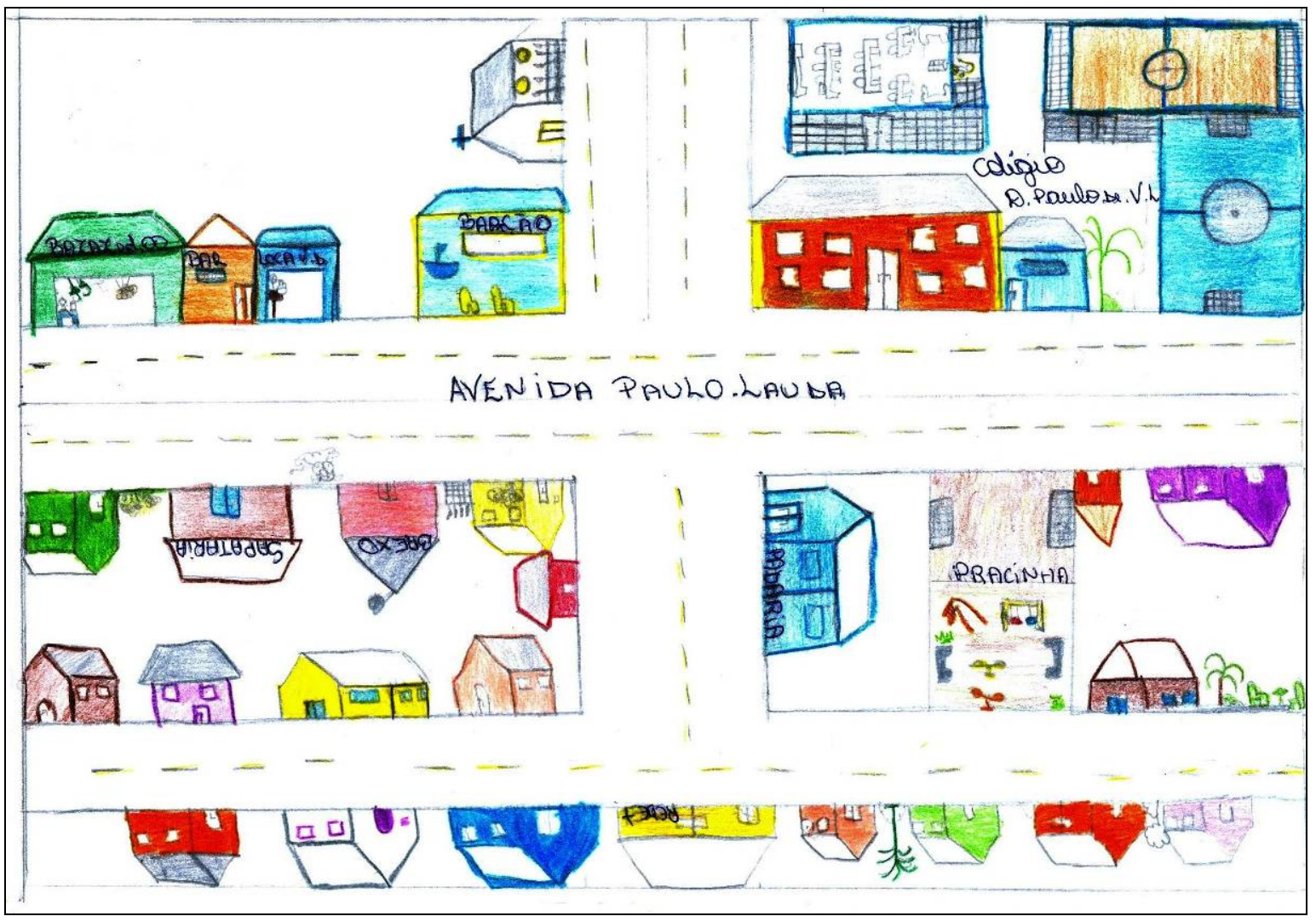

Figura 13 - Mapa mental do aluno 2 ANTES da utilização da imagem de satélite do bairro.

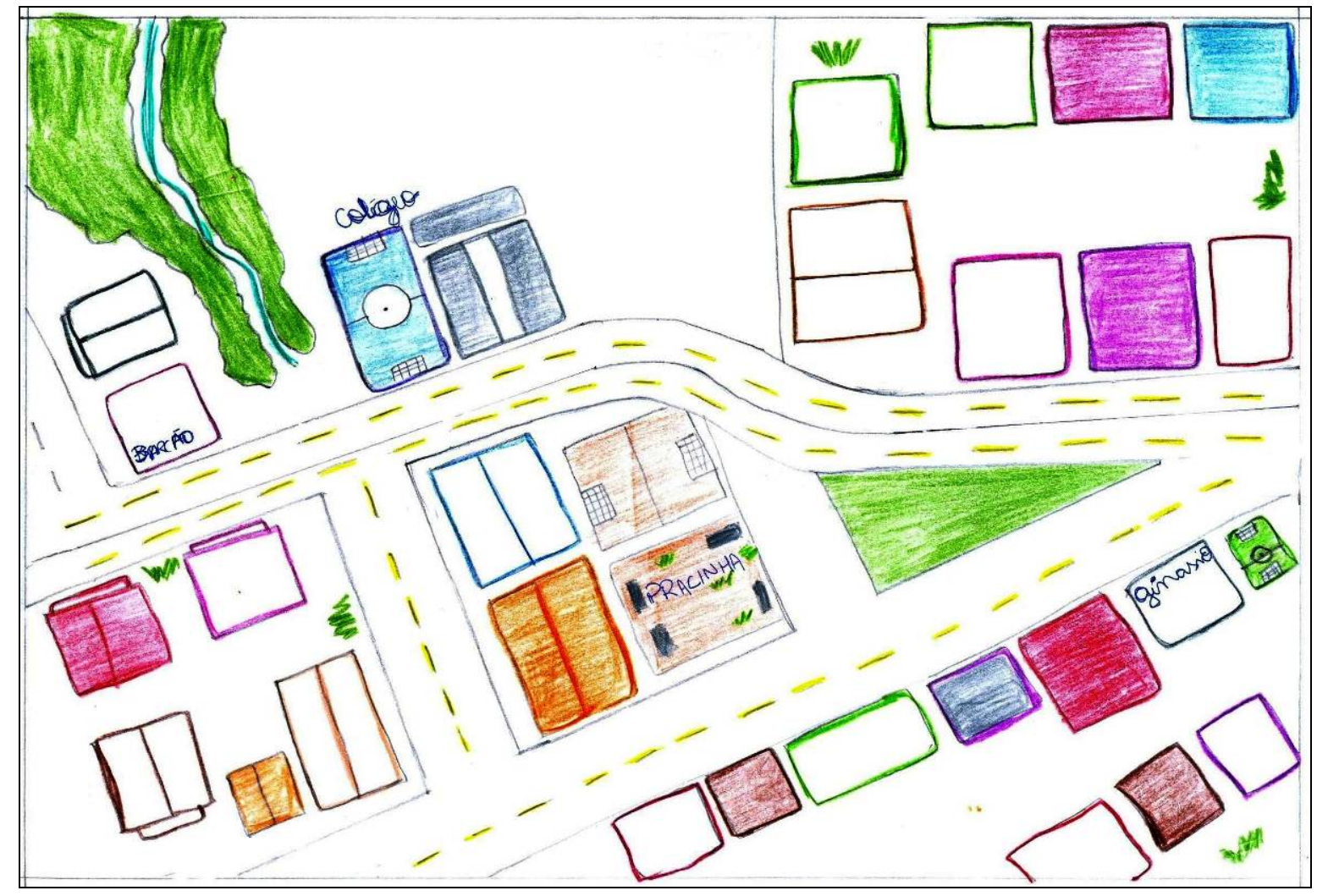

Figura 14 - Mapa mental do aluno 2 APÓS a utilização da imagem de satélite do bairro. 


\section{CONSIDERAÇÕES FINAIS}

A partir da realização do presente trabalho foi possível contemplar o objetivo de desenvolver e avaliar uma seqüência didática para o estudo da categoria lugar com o auxílio de imagens de satélites e outros materiais didáticos, o que permitiu algumas considerações sobre sua utilização com alunos de $5^{\text {a }}$ série, com faixa etária média de 10,8 anos.

Em forma de desenhos, os alunos representaram seus locais de vivência de acordo com suas experiências do cotidiano. Ao desenhar, os alunos geraram no papel traços refletidos de seu íntimo, a visão que tem do lugar onde vivem, expressando emoções que muitas vezes são difíceis de reproduzir através da comunicação escrita. Os alunos representam lugares que agradam a eles, refletidos de lembranças agradáveis, com representações coloridas como elementos da natureza, locais de lazer, sua casa, locais que gostam de freqüentar, dentre outros. Também representaram locais de repulsão, com poucos traços e cores e outros fatores que dependerão da sensibilidade do observador dos desenhos compreenderem os sentimentos empregados pelos alunos.

Foi constatada primeiramente uma dificuldade dos alunos ao retratarem seu lugar de vivência de uma visão horizontal nos desenhos, para uma visão vertical nos mapas mentais. Grande parte dos alunos ultrapassou essa dificuldade após trabalharem com imagens de satélite, que é uma representação em visão vertical. Neste sentido, o professor deve trabalhar estes os conceitos de visões das representações de mapas, desde a alfabetização cartográfica, em que serão consolidadas as noções que o aluno precisa ter para ser um mapeador consciente (SIMIELLI, 1999).

Através do uso de imagens de satélite em diferentes escalas, que foram do global (Terra, América do Sul, Brasil, Rio Grande do Sul) ao local (Santa Maria e Bairro Tancredo Neves), foi possível proporcionar aos alunos conhecimentos espaciais e visões que geralmente não é possível observar em uma visão a partir de um ponto da superfície terrestre.

A interpretação da imagem de satélite do bairro mostra que os professores precisam dar mais ênfase ao estudo do espaço vivido dos alunos, para que possam juntos preencher as lacunas existentes nos conceitos geográficos que muitas vezes são confundidos pelos alunos ao analisarem as imagens de satélite. Desse modo, o estudo das imagens de satélite, da chave de interpretação de imagens atuando juntamente com 
o conhecimento prévio dos alunos de seu local de vivencia são de grande valia no processo de ensino-aprendizagem da categoria lugar.

As imagens de satélite compreenderam um eficiente material didático para o entendimento da visão vertical. Através das imagens os alunos puderam observar os objetos vistos de cima, refletindo suas observações no segundo mapa mental confeccionado, após a utilização de imagens de satélite e não mais como no primeiro mapa mental em que grande parte dos alunos representou parcialmente objetos constituintes do seu lugar de vivência, conforme suas visualizações das laterais destes objetos.

As imagens de satélite proporcionaram motivação aos alunos para realização do estudo do lugar. Através das imagens os alunos puderam verificar as localizações de locais conhecidos por eles e ampliar sua visão sobre o seu espaço vivido, que antes estava voltado principalmente a sua casa, rua e vizinhança, passando a verificar que outros elementos estão presentes em seu cotidiano. Os mapas mentais foram capazes de mostrar como o aluno vê e interpreta o meio em que vive, do mesmo modo que também mostraram atribuições de valores diferenciados para o mesmo espaço em que estão inseridos, ou seja, os locais com os quais indiretamente eles mais se identificam no bairro.

A análise dos mapas mentais proporcionou os principais indicadores de ampliação do conhecimento espacial do lugar de vida dos alunos. Com o uso de imagens de satélite como recurso para melhorar seu conhecimento do lugar, constatou-se que a maioria dos alunos representou seus mapas mentais com maior complexidade e os objetos representados com melhor arranjo espacial, condizendo mais com a realidade em comparação com os mapas anteriormente confeccionados, sem a anterior visualização da imagem de satélite. Estes alunos tiveram melhores rendimentos por estarem na fase de transição do estágio cognitivo operatório concreto (7 a 12 anos) para o operatório-formal ou abstrato (após os 12 anos), sendo que uma das principais estratégias cognitivas desenvolvidas nesta fase é a capacidade de raciocinar de maneira hipotético-dedutiva, habilidade de grande utilidade para a interpretação de imagens de satélite (CORAZZA, 2009).

O menor rendimento de alguns alunos em interpretar as imagens de satélite e manter o mesmo nível de espacialização dos elementos geográficos nos mapas mentais, deve-se principalmente ao estágio cognitivo no qual se encontram (operatório-concreto). Pela média de idades dos alunos que apresentaram este resultado ser menor que os demais, demonstra 
que alunos do estágio operatório concreto apresentaram um desempenho mais baixo do que os alunos em fase de transição para o operatório formal.

Com o auxílio da imagem de satélite para o estudo do lugar, o professor é capaz de identificar como o aluno compreende a sociedade no qual está inserido. O estudo das imagens mentais confeccionadas pelos alunos após o trabalho com as imagens de satélite, permite que o professor auxilie o aluno a preencher as lacunas existentes em seu entendimento de espaço vivido, adquirido através seu cotidiano, construindo em nível participativo seu conhecimento geográfico.

Destaca-se também que através das imagens de satélite empregadas no estudo do lugar, os alunos puderam ter uma melhor visualização e entendimento dos problemas ambientais do bairro, principalmente dos próximos à escola. Através da localização destes locais de impactos ambientais na imagem, mostraram interesse na temática ao discutirem a ocorrência, tirarem fotos e apontaram as causas e conseqüências destas irregularidades do espaço, mostrando algumas vezes possíveis soluções para estes casos, como a conscientização da população que reside perto destes locais.

Verificou-se que explorar elementos do local de vivência, possibilitará que os alunos também desenvolvam e elaborem questões e análises críticas do global. O professor deve tratar o local não como o ponto de partida para o estudo do global, mas sim relacionálos entre si. Sendo assim, cabe ao professor trabalhar o concreto com o aluno, abrindo caminhos para o entendimento e relações com outros espaços e escalas espaciais.

Pode-se avaliar que a seqüência didática aplicada é eficiente, visto que propicia aos alunos um desenvolvimento do conhecimento sobre seu lugar de vivência. Através dos resultados obtidos em cada atividade, o professor poderá trabalhar os conceitos geográficos envolvidos e verificar as dificuldades dos alunos, assim direcionando suas explicações. O professor ao estruturar o planejamento da sua aula, utilizando novas técnicas, como o produto do sensoriamento remoto, além de estar experimentando outras propostas pedagógicas, estará qualificando o processo de ensino-aprendizagem na disciplina de Geografia.

O desenvolvimento deste trabalho demonstra a necessidade da iniciativa dos professores de Geografia em buscar novos meios de tornar o ensino de Geográfica, uma ciência que trabalha com a vivência, o cotidiano dos alunos, sempre com uma atividade atrativa e prazerosa. O uso de produtos de sensoriamento remoto, desperta nos alunos o 
interesse pelos conteúdos geográficos, as imagens de satélite faz com que desejem compreende-los e desvendar tudo o que eles podem mostrar.

\section{REFERÊNCIAS}

BRASIL. Ministério da Educação e do Desporto. Secretaria de Educação Fundamental. Parâmetros Curriculares Nacionais: terceiro e quarto ciclos do ensino fundamental: Geografia. Brasília: MEC, 1998.

BRUNINI, Lucas Vinícius. O mapa mental: percepção do espaço e identidade no processo ensino-aprendizagem da geografia. Disponível em: $<$ http://www.unifev.edu.br/graduacao/artigos.php?id=36> Acesso em: 22 de novembro de 2009.

CALLAI, Helena Copetti. Estudar o lugar para compreender o mundo. In: CASTROGIOVANNI, Antonio Carlos (Org.). Ensino de Geografia. Porto Alegre: Ed. Mediação, 2002, p. 83-153.

CAVALCANTI, Lana. Geografia, escola e construção de conhecimentos. Campinas: Papirus, 1998.

CONSTRUIR NOTÍCIAS. A importância dos mapas e dos Atlas. Espaço Pedagógico. Disponível em: < www.construirnoticias.com.br/materia.asp?id=506 >. Acesso em: 22 de novembro de 2009.

CORAZZA, Rosana. O uso de imagens de satélite no ensino de geografia sob a ótica piagetiana. Trabalho de Graduação (Licenciatura Plena em Geografia), Universidade Federal de Santa Maria, Santa Maria, 2008.

FLORENZANO, Teresa Gallotti. Imagens de satélite para estudos ambientais. São Paulo: Oficina de Textos, 2002.

KRAMER, Gisieli; et. al. O uso do sensoriamento remoto como recurso didático para o ensino da Geografia no sexto ano do Ensino Fundamental. In: Simpósio Brasileiro de Sensoriamento Remoto (SBSR), 14, 2009, Natal - RN. Anais... Natal, 2009. p. 2429-2435.

MORGADO, Vânia Nunes. O conteúdo simbólico dos elementos que constituem o lugar - o cotidiano do aluno no ensino de Geografia. Disponíevel em < http://www.anped.org.br/reunioes/25/posteres/vanianunesmorgadop12.rtf> Acesso: 22 de novembro de 2009.

MÓTA, Patrícia Nascimento. O estudo do lugar a partir do uso de imagens de satélites com alunos de $4^{a}$ série do ensino fundamental. Dissertação (Mestrado), Universidade Federal de Santa Maria, Santa Maria, 2007. 
PEREIRA, Thaís. O Sensoriamento Remoto como recurso didático no ensino fundamental. Dissertação (Mestrado). Universidade Federal de Uberlândia, Uberlândia, 2007.

PILETTI, Claudino. Didática geral. São Paulo: Ática, 1991.

SANTOS, Clézio. O uso dos desenhos no ensino fundamental: imagens e conceitos. In.: Geografia em perspectiva: ensino e pesquisa. PONTUSCHKA, Nídia Nacib; OLIVEIRA, Ariovaldo Umbelino de (Orgs.). 3.ed. São Paulo: Contexto, 2006.

SANTOS, Felipe Correa; et. al. Desenvolvimento do CD-ROM "O Sensoriamento Remoto como recurso didático no estudo do município de Santa Maria-RS”. In: JORNADA DE EDUCAÇÃO EM SENSORIAMENTO REMOTO NO ÂMBITO DO MERCOSUL, 7., 2009, Santa Maria. Anais... Santa Maria, 2009.

SANTOS, Milton. Metamorfoses do espaço habitado. São Paulo: Hubitec, 1998.

SANTOS, Vânia Maria Nunes dos. Escola, cidadania e novas tecnologias: o sensoriamento remoto no ensino. São Paulo: Paulinas, 2002.

SILVA, Fábio Gonçalves; CHAVES, Joselisa Maria. Imagens de Sensoriamento Remoto como subsídio para o Ensino de Geografia em Feira de Santana (BA): experiências em escolas públicas do município. In: JORNADA DE EDUCAÇÃO EM SENSORIAMENTO REMOTO NO ÂMBITO DO MERCOSUL, 7., 2009, Santa Maria. Anais... Santa Maria, 2009.

SIMIELLI, Maria Elena R. Cartografia no ensino fundamental e médio. In: CARLOS, Ana Fani Alessandri (Org.). A geografia na sala de aula. São Paulo: Contexto, 1999. p. 92-108.

TUAN, Yi-fu. Topofilia: um estudo da percepção, atitudes e valores do meio ambiente. São Paulo: Difel, 1980.

TUAN, Yi-fu. Espaço e lugar: a perspectiva da experiência. São Paulo: Difel, 1983.

VIERO, Lia Margot Dornelles. Atlas Escolar Municipal - Evolução PolíticoAdministrativa Santa Maria - RS. 2007.

Enviado para publicação em julho de 2010.

Aceito para publicação em outubro de 2010. 